
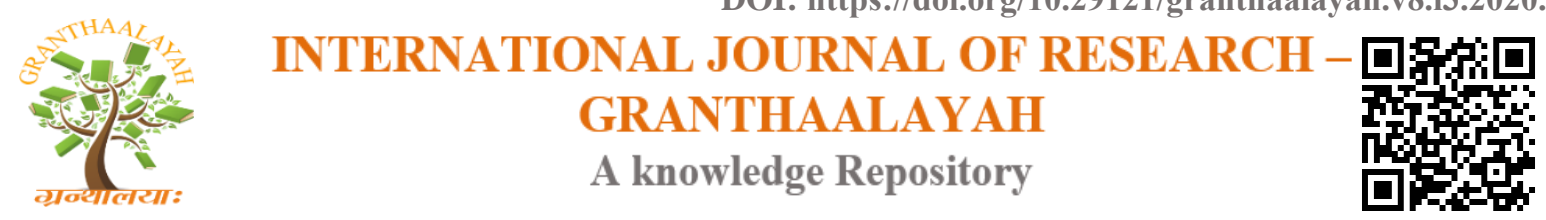

Management

\title{
SWASTIRBHAVATU- SUSTAINABLE DEVELOPMENT OF THE COMMUNITY
}

\author{
Bhattacharya $\mathbf{T}^{* 1}$ \\ ${ }^{*}$ Department of Hospital Administration, Armed Forces Medical College, Pune, India
}

\begin{abstract}
Man is a social animal and the niche he inhabits is his society. The units of this society serve tasks like education of the children, skill development of adults, care of the unhealthy, support of the infirm, maintenance of health in totality, rearing of the animals and trees to enhance living conditions among many others. Extrapolating the present arena of decline in emotional sensitivity of curricula, varied importance of different sections, unworthy approach to old and disregard of environment - the succession of the Homo sapiens appears bleak. The increasing carbon footprint and no cessation in the nature/ intent of using the resources endangers the physical existence too. This paper propounds the philosophy of a way to annihilate the shortcomings of the activity units -may be in a traditional fervor- to find a novel solution to the several questions confronting us. The resultant of this would be ignited minds receptive to changes, skilled personnel in every field irrespective of the differences and their coexistence eliminating conflict, amalgamation of the old guard of the homes as directing flags of the fleet of society and development of a holistic environment.
\end{abstract}

Keywords: Swastirbhavatu (Sanskrit) May There Be Auspiciousness; Activity Unit; Gurukul; Kalas (Sanskrit)Arts in multitude; Mahabharata (Sanskrit epic); Blue Zone.

Cite This Article: Bhattacharya T. (2020). "SWASTIRBHAVATU- SUSTAINABLE DEVELOPMENT OF THE COMMUNITY." International Journal of Research Granthaalayah, 8(3), 266-270. https://doi.org/10.29121/granthaalayah.v8.i3.2020.152.

\section{Introduction}

The world we see around us, as we notice the way things are going; do we really have a problem? Or is it going absolutely fine? Is it a fool's paradise or a real paradise with paradigm views. A child goes to school learning things and acquiring skills day in and out. But what is it that defines the persona of the child? Schools of Engineering, Sciences, Medicine, Humanities, Commerce, Finance, Marketing ... Is that Zenith of all that we have to teach? Earn livelihood, work to earn name-fame-play game- build house, rear children, making them learn the same thing over and over again because the adults are engrossed in work- get old, lose the charm as if it never existed! Going beyond our limits using artificial intelligence, are we losing contact of the real-time emotions and social intelligence? 


\subsection{Reinventing the Wheel}

The concept of the individual and the immediate environment is put forth as a composite system. The individual is the sole existing entity which when considered as a whole, the universe goes in the background -as good as non-existent. The situation goes absolutely different when considered from the diametrically opposite view. The nonexistent environment now becomes infinite comparable to the summation of both the functions-the universe. The individual infinitesimally small, becomes a significant factor when considered as a function of the second factor.

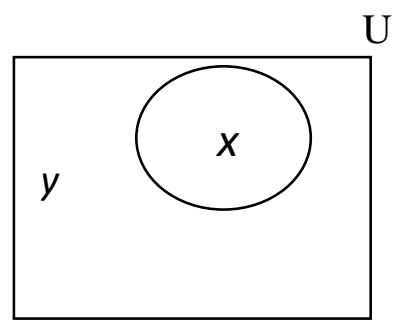

$$
\mathrm{x}=\text { man, } \mathrm{y}=\text { nature, } \mathrm{U}=\text { universe( } \text { (society) }
$$

$\boldsymbol{X}=\mathbf{1} \quad$ (y becomes irrelevant)

$\mathrm{X}$ becomes the wholesome to reckon with till the point in time and space when $\mathrm{x}$ implodes or explodes to become the universe.

This translates as- man considering himself to be supreme. Develops technology to maximize himself and his ambitions to the zenith. Total disregard for Nature in turns eliminates the surrounding. Lime and mortar replaced by concrete, men replaced by machine and alike. At some point the revenge happens- calamities/ disease/mishap. The End.

The alternative;

$\boldsymbol{x}=\boldsymbol{f}(\boldsymbol{y}) \quad$ (x being infinitely small becomes significant when considered a function of $\mathrm{y}$ )

$\mathrm{X}$ now becomes substantial enough till the point in time and space when $\mathrm{x}$ is almost comparable to the universe. The nature synergizes to help the functions coexist and attain their culmination existing mutually over millennia.

First glance, the set of equations would appear to be extraordinary, however within moments they stand nowhere under the Sun. Considering the Newtonian principles the significance of these words would stand insurmountable.

\subsection{The Concept}

The activity units of the society serve tasks like skill development/ imparting knowledge to the children, care to the unhealthy, support to the infirm, rearing of the animals and trees to enhance living conditions and continuously explore the options of sustaining life on basic essential principles among many others(1). The society thus conceived would appear absolutely basic, the importance of the same can well be extrapolated to wellness not just physical but also social, mental, economic and spiritual (2). 
Discussing the four fundamental principles of Nobel laureate Rabindranath Tagore's idea of educational philosophy (4)-

1) Naturalism

2) Humanism

3) Internationalism

4) Idealism

The education system of gurukul being propounded is an in-house training of the students to extracurricular and co-curricular activities to make a person perfect in various faculties of life (3). The techniques would have the traditional fervor but with an approach modern- incorporated into the educational system raising the standards from literates to knowledgeable ones.

The child would get a life closer to earth living in houses of mud/ stone / wood made by artisans who would in turn be benefitted by rejuvenation of their art, which has been losing its fervor in the dust of concrete and metal. This does not mean that rapid industrialization and booming manufacturing industry is the curse to reckon with, but the significance has to be made relevant to the young minds that - "there is something more". The various faculties of learning now organized into Science- Arts -Humanities have become watertight compartments where the individuals exist in isolation. The children will be given options of learning absolutely tangential arts ranging from archery, boating, agriculture, horticulture, pisciculture, painting and pottery. Preference would be given to writing, literature, grammar, language whether oriental or new as is found to fascinate the comprehensive capability of a pupil. Considering sciences students will be primed from geometry to geography, history to anthropology, astrology to astronomy whatever and whichever field fascinates the mind of the student as well as what fits in the caliber acquired over the years at the residential school.

Skills developed in the children would be immense and intelligence much ahead of contemporary brilliance!

\section{Materials and Methods}

\subsection{The Men}

The hospital would help treating the patients regain their health regardless the social stature- cases of chronic debilitation like Tuberculosis, Hansens, Acquired Immune Deficiency Syndrome, Hepatitis B/C to name a few. Use of traditional medicine may well be extrapolated with healing practices of chiropatry, astrology, reiki, su-jok, accupunture to acupressure. The scope may well be extended to the non-communicable diseases related to lifestyle. The treatment modality may not be necessarily limited by watertight compartments but by novel techniques suggested by age old tenets of Ayurveda that may well be tested for validity/ accreditation standards by experts in the field.

Care of infirm will include the older generation which is a sort of outcaste to the fast-moving younger lot on account of thinking, strength, mindfulness and experience. The people will also be pathfinders for the younger lot involving themselves in activities and thus retaining their 
connection to society at large. Yoga training, sleep studies, alternative therapies and allied fields will be provided and serve to develop serenity in lives of the group of people in the project.

\subsection{The Interaction with Surroundings}

The animal husbandry unit of this project will work to rear domestic animals like cows in addition to a few more animals depending on the area where the project is being executed. Cow milk will be used for consumption by the people, production of milk products to sustain livelihood and at a later stage for commercial purposes.

Plants will be an extremely sensitive part of the project as a whole to reduce the carbon footprint generated. Homa method of farming would be adopted by the people (5). Elaborating the method - the trees and plantation would be grown on soil devoid of usage of artificial chemicals. The dried leaves and twigs would be sacrificed using firewood and dried animal dung reciting prayers for good health of the vegetation. The fumes would drive away the pests and the remnant ash will serve as ultimate carbon fertilizer to the trees.

\section{Results}

The people living in the conglomerate would be eternally bound. No dearth of love and emotions. No fear of money and amassing the extras. The society, if adopted a system of barter - cloth sewed in exchange of a pot of clay and honey bucketful for a bundle of silk. Two fishes fetched from the stream to be given in return of a pot of rice and few vegetables cooked for a bunch of salads grown in the backyard. Evenings would be time to discuss issues together and solved there itself. Reciting prayers and rejoicing over hymns of eternal life and the Supreme would be the idea to reckon with. The idea seems to be a revolutionary one- appearing as if we plan to go back from the present age of robust technological prowess. Why go into the abyss when there is ample resource to go far ahead into the skies? The older tenets of Babylon/Mesopotamia/Harappa only prove ratifications of the same concept. The reason these ancient societies perished is similar to that of the present day.

\section{Conclusion}

Redefining the social fabric would entail empowerment of the units. The Empowerment of an individual would not only mean physical but also mental and not to forget the then higher dimension of emotional empowerment. (6) Empowered individuals would make empowered families and in turn make a vibrant society sustaining the nectar of contentment.

The society thus maintained would neither harbor lawlessness nor will need an administration for the basic reason -the absence of conflict. (7) As said by Russel Bertrand we have arrived at a later stage of conflict:

\begin{tabular}{|l|l|l|}
\hline \multicolumn{2}{|l|}{ Conflict within } & Result \\
\hline Man & Nature & Infections \\
\hline Man & Man & Wars / Homicide \\
\hline Man & Self & Lifestyle Disorders \\
\hline
\end{tabular}


A contented society quoted from the age of Mahabharata (3500BC)- Neither There Was A Ruler Nor They Needed To Be Ruled, Neither The Need Of Punishments Nor A Solemn Guard! It Was Righteousness That Guided The People Who Took Care Of Each Other Adept! (8)

Fairytale rendition as it would appear to be, but I refute the charge diligently! The centurions inhabiting Okinawa, Japan stand for the philosophy rendered in this article. This is an adaptation of the Japanese concept of Ikigai that indicates the value of one's life and mission of life that one wants to live for.(9) This land inhabited by people -happy, busy in their daily chores, a unit of bonding to reckon with and sustaining each other is called Blue Zone which also exists in Sardinia(Italy), Nicoya(Costa Rica) and Icaria(Greece) among a few more.

\section{Acknowledgements}

a) Dr. Surekha Kashyap for her idea of education and empowerment. 'we have sort to empower the women by educating them of their rights and giving them the right to go ahead. But wat about the other sex? If men are not equally impressed upon, not educated of their counterparts' value will they ever respect the already empowered gender infront of them? That is how the society is presently growing!!'

b) Dr. Amitav Banerjee for his idea of development of conflict and how we cwn mitigate them as described by Russel Bertnard.

\section{References}

[1] A Vedic Prayer of Swasti: Aum, bhadram karnebhih srunuyāma devāh \| Bhadram pasyema aksabhir yajatrāh || Sthirair angais tustuvām sastanūbhih || Vvyasema devahitam yadāyuh || Swasti na indro vridhasravāh || Swasti nah pūsā viswavedāh || Swasti nastārksyo aristanemih|| Swasti no brihaspatir dadhātu || Aum, santih, santih, santih \|

[2] Meaning: Aum! May our ears hear what is good and auspicious. May our eyes see d auspicious. For the sake of gods, may we fully live the ordained span of our lives with good health and strength. May Indra who is extolled in the Vedas, Pusan, the lord of the world, Tarksya, who saves us from harm, Brihaspati who fosters our intelligence grant us prosperity as we are engaged in the study of the scriptures and the practice of truths in them. Aum peace here, peace above and peace all around.

[3] Health is a state of complete physical, mental and social well-being and not merely the absence of disease or infirmity. (WHO definition of health accepted at Alma Ata)

[4] 64 kalas https://en.wikipedia.org/wiki/Kal\%C4\%81

[5] Rabindranath Tagore's philosophy of Indian Education; Bhoomi magazine February 6, 2018

[6] Agnihotra.org- homa method of farming.

[7] Adopted from speech of Dr Surekha Kashyap on women empowerment

[8] Adopted from speech of Dr Amitava Banerjee on conflict stages propounded by Russel Bertrand.

[9] Adopted from Ekatma Manav Darshan by Sankalit and translated

[10] Ikigai by Hector Garcia and Albert Liebermann.

\footnotetext{
*Corresponding author.

E-mail address: bhtarapranav@gmail.com
} 